\title{
The Analysis to the Profit of Commercial Banks in the Process of Interest Rate Marketization
}

\author{
Lulu Guo \\ School of Economics, Shanghai University,P.R China \\ 1246643014@qq.com
}

Keywords: Marketization of interest rate; Interest rate; Commercial banks; Profit

\begin{abstract}
In view of the commercial Banks faced in the process of marketization of interest rate situation, define the meaning of interest rate marketization. On the basis of predecessors' rich theory as guidance, through to in the process of interest rate marketization of the main factors influencing the commercial bank profitability analysis, and by comparison with detailed data and empirical econometric analysis to examine the profitability of commercial Banks, to grasp the marketization of interest rate under the commercial bank profits for the key. Suggested that commercial Banks under the marketization of interest rate change business types, improve the pricing power, perfecting the interest rate risk control system. Thus improve the bank market share and increase revenues.
\end{abstract}

\section{Introduction}

At present, there are many problems in China's commercial banks. Nicholas Lardy (2012) pointed out that the control of the Chinese central bank would lead to commercial banks to obtain far more than the normal level of profits. And this profit is not conducive to commercial banks to improve operational capacity and risk control capabilities, but also detrimental to the improvement of China's financial system[1].Laeven L and Valencia F (2013) conducted empirical analysis of the data on crisis responses in the 1970-2011 systemic banking crisis[2]. Li Zhonglin (2015) pointed that the overall risk of domestic commercial banks is lower than the optimal risk taking level[3].

Zhou Bing (2013) draws lessons from the reform experience of foreign interest rate marketization, qualitatively divides the process of interest rate marketization into four important stages[4].Tarhan Feyzioglu, Nathan Porter and Elod Takdts (2009) have the view that the release of the deposit interest rate ceiling is the focus work of the Chinese government [5].Li Kechuan and Yang Yi (2013) focus on the analysis of the environment faced by the small and medium-sized commercial banks in the process of market-oriented interest rate reform. It is both an opportunity and a challenge[6].

The purpose of this paper is to analyze the profitability of commercial banks by analyzing the relevant profit indicators of commercial banks. And in this case, hope this paper can provide appropriate recommendations for the future development of commercial banks .

\section{Analysis of Theoretical Mechanism}

Profit source of commercial bank. The profit sources of commercial banks mainly include two parts: interest income and non-interest income. It is well known that the main source of profit for commercial Banks is interest income, especially before the interest rate marketization, and the government created a huge surplus for commercial Banks through interest rate controls. Non-interest income mainly refers to the income obtained through intermediary business, as well as related business income such as investment, consulting, management and so on.

The main factors that affect the profitability of commercial banks. There are many factors that affect the profitability of commercial banks, such as spreads, non-interest income, total assets and non-performing loan ratio.

Net interest spread (NIS), which is the main factor affecting the profitability of commercial banks. Net interest spread $=($ interest income - interest expense) $/$ total assets, which measure the ability to receive net interest income from the bank's total assets. The higher the ratio, the higher the ability to 
generate interest income from bank assets.

loan ratio $(\mathrm{LDR})=$ total loans / deposits is a measure of the liquidity of commercial banks. The higher the total amount of loans, the higher the profitability.In order to control the risk of commercial banks, the regulatory authorities will be strictly concerned about the situation of the indicators.Generally speaking, it is safe for commercial banks that the indicators do not exceed $75 \%$ of the case of operating conditions.

Nonperforming Loan Rate (NPL)[8]= Total NPL / Total Loan. After the issuance of loans by commercial banks, due to changes in the economic environment or changes in their own operating conditions, some loans will inevitably occur in some or all of the situation can not be repaid. This will inevitably impact on the profitability of commercial banks. Non - bank social financing ratio(NSF) $=$ non - bank social financing scale / social total financing. It mainly measure the changes in the scale of loans of commercial banks.

\section{Empirical analysis}

Variable selection. Selection of dependent variable:there are many indicators to measure the performance of commercial banks. we use ROA and ROE as usual. For these two indicators: ROE = net profit / net assets, the main measure of the return on assets invested by shareholders. However,the company can get higher income so we use ROA to measure the rate of return of the total assets through debt operations.

Selection of independent variables: we choose the net interest spread (NIS), non-interest income ratio (UN), nonperforming loan interest rate (NPL) and non-bank social financing ratio (NSF) to analyze the profitability of commercial banks.

Research samples and data sources. taking 16 commercial banks in 2007 - 2014, a total of 8 years of data on the process of interest rate liberalization of commercial banks in the interest rate for the simple to analyzes the profitability of commercial banks in the process of interest rate marketization by empirical analysis of the impact of these variables on the rate of return on total assets. The variables are from the Guotaian database. This article uses Eviews8.0 to carry on the econometric analysis. Table 1 shows the relevant data collected:

Table 1 Statistics and description of each variable

\begin{tabular}{|c|c|c|c|c|c|c|c|}
\hline & Definition & Variable definitions & $\begin{array}{c}\text { Observatio } \\
\text { ns }\end{array}$ & $\begin{array}{c}\text { Average } \\
\text { value }(\%)\end{array}$ & $\begin{array}{l}\text { The maximum } \\
\text { value }(\%)\end{array}$ & $\begin{array}{c}\text { Minimum } \\
\text { Value }(\%)\end{array}$ & $\begin{array}{c}\text { Standard deviation } \\
(\%)\end{array}$ \\
\hline ROA & $\begin{array}{r}\text { Total return } \\
\text { on assets }\end{array}$ & $\begin{array}{l}\text { Net profit / average } \\
\text { total assets }\end{array}$ & 128 & 1.3 & 1.68 & 0.15 & 0.234 \\
\hline NIS & $\begin{array}{l}\text { net interest } \\
\text { spread }\end{array}$ & $\begin{array}{l}\text { (interest income - } \\
\text { interest expense) / } \\
\text { total assets } \\
\end{array}$ & 128 & 2.33 & 3.42 & 0.27 & 0.346 \\
\hline UN & $\begin{array}{l}\text { non-interest } \\
\text { income ratio }\end{array}$ & $\begin{array}{l}\text { Non-interest income } \\
\text { / operating income }\end{array}$ & 128 & 18.73 & 32.47 & 5.49 & 6.39 \\
\hline NPL & $\begin{array}{c}\text { nonperforming } \\
\text { loan interest } \\
\text { rate }\end{array}$ & $\begin{array}{l}\text { Total NPL / Total } \\
\text { Loan }\end{array}$ & 128 & 1.38 & 2.36 & 0.36 & 2.12 \\
\hline NSF & $\begin{array}{c}\text { non-bank } \\
\text { social } \\
\text { financing ratio }\end{array}$ & $\begin{array}{l}\text { non - bank social } \\
\text { financing scale / } \\
\text { social total financing }\end{array}$ & 8 & 13.25 & 17.2 & 11.1 & 2.12 \\
\hline
\end{tabular}

Source: Cathay Pacific Database

Model building: the model can be set as follows.

$$
\operatorname{LnROA}=\beta_{0}+\beta_{1} \operatorname{LnNIS}_{i t}+\beta_{2} \operatorname{LnUN}_{i t}+\beta_{3} \operatorname{LnNLPL}_{i t}+\beta_{4} \operatorname{LnNSF}_{i t}+\varepsilon_{i t}
$$

Where $\mathrm{i}$ is the total number of 16 commercial banks, so the value is 1 to 16 . Select relevant data included the 16 banks from 2007 to 2014 for empirical research. $t$ value is the total number of annual reports of commercial banks during the period. This chapter focuses on analysing the impact of various factors on the profitability of commercial banks by using the empirical 
methods.Firstly, We need to perform a unit root test on the original sequence. If the result of the test is stable, then the regression is carried out.If the result of the test is unstable,a first-order differential unit root test of the variable is required until a stable conclusion is reached.

In order to prove the correlation between the variables, The panel data were covariantly tested to analyze whether there was a stable long-term correlation between the variables.If there is a stable long-term correlation between the variables, we can carry out the regression of panel data, according to the F statistic to select model which is the variable coefficient model, variable intercept model or mixed model. And the selection of the fixed effect model or the random effect model was determined according to the Hausman test.

Parameter inspection. Unit root test[9]:The purpose of using the unit root test is to test the smoothness of the variables and to prevent "pseudo-regression". We use the LLC test and the ADF test.The LLC test is used to verify that all individuals have the same unit root and the ADF test is used to verify that all individuals have different unit roots. The test results are shown in Table 2 :

Table 2 Unit root test results

\begin{tabular}{c|c|c|c|c|c}
\hline & LLC & P & ADF & P & conclusion \\
\hline LN(ROA) & 2.5791 & 0.9950 & 18.6464 & 0.9710 & unstable \\
\hline LN(NIS) & -6.1151 & 0 & 25.7511 & 0.7745 & unstable \\
\hline LN(UN) & 3.2923 & 0.9995 & 23.9177 & 0.8474 & unstable \\
\hline LN(NPL) & -3.6958 & 0.0001 & 26.5383 & 0.7393 & unstable \\
\hline LN(NSF) & -5.9792 & 0 & 39.8474 & 0.1605 & unstable \\
\hline
\end{tabular}

As the test results are not smooth, so the first-order check on the variables and then test, the test results are shown in Table 3 :

Table 3 Unit root test results

\begin{tabular}{c|c|c|c|c|c}
\hline & LLC & P & ADF & P & conclusion \\
\hline D(LN ROA) & -21.9986 & 0 & 89.5585 & 0 & stable \\
\hline D(LN NIS) & -21.5155 & 0 & 64.2234 & 0 & stable \\
\hline D(LN UN) & -18.9157 & 0 & 80.8596 & 0 & stable \\
\hline D(LN NPL) & -22.9709 & 0 & 78.7297 & 0 & stable \\
\hline D(LN NSF) & -12.9976 & 0 & 58.4180 & 0.0029 & stable \\
\hline
\end{tabular}

So We can carry out cointegration test on the basis of the first-order difference of each variable according to the results.

Cointegration test:Next, we test whether there is a long-term equilibrium relationship between the variables by using the cointegration test. In this paper, we use the Kao test and Pedrori test of Engle-Granger methods to perform cointegration test. The test results are shown in Table 4 :

Table 4 The results of the cointegration test

\begin{tabular}{c|c|c|c}
\hline & Kao Test statistic & \multicolumn{2}{|c}{ Pedrori Test statistic } \\
\hline Testing method & ADF-Kao & Panel ADF & Group ADF \\
\hline Result & $-5.9942(0)$ & $-3.2123(0)$ & $-5.4283(0)$ \\
\hline
\end{tabular}

Test results: $\mathrm{P}<0.05$ means that at $5 \%$ of the significant level, there is a long-term equilibrium between the various variables and lay the foundation for our next model regression.

Model estimation:By comparing the values of the $\mathrm{F}$ statistic, we choose the variable intercept model (the coefficient term is constant). Followed by Hausman test[10], the test results as shown in Table 5 :

Table 5 Hausman Test result

\begin{tabular}{ccc}
\hline Cross-section random & Chi-Sq. Statistic & Prob \\
\hline $4-1$ & 2.4093 & 0.6610 \\
\hline
\end{tabular}

From the test results, the value of the statistic is 2.4093 and the $\mathrm{P}$ value is $0.6610>0.05$. 
Therefore, the random effect model should be selected for regression. The regression results are shown in Table 6:

Table 6 Model regression results

\begin{tabular}{cccccc}
\hline & C & NIS & UN & NPL & NSF \\
\hline coefficient & 0.0024 & 0.1909 & 0.0019 & -0.0018 & 0.0183 \\
T statistic & 1.016 & 3.8883 & 2.1184 & -2.2540 & 2.4975 \\
P & 0.3117 & 0.0002 & 0.0361 & 0.0260 & 0.0138 \\
\hline
\end{tabular}

From the empirical results, we can see that the coefficient of net interest rate is larger than the non-interest income, which shows that the interest income is still the main source of income for the bank in the interest rate marketization stage. The $\mathrm{P}$ value of the constant term is 0.3117 and is not passed. But in the whole regression equation, the constant term has little effect and can be ignored.

The NPL ratio also plays an important role in the profitability of commercial banks. Based on the test results, the coefficient of nonperforming loan interest rate is -0.0018 , indicating a reverse change from bank profit. With the marketization of interest rates, commercial banks should gradually reduce the non-performing loan rate, do a good job of pre-loan review and post-loan management.

The results of non-bank social financing are contrary to the assumptions. According to experience, the increase in the proportion of non-bank social financing represents the narrowing of the scale of bank loans. This conclusion is inconsistent with the experience may due to the larger fluctuations in the stock market .

The better the stock market, the higher the proportion of non-bank social financing. In the latter part of the liberalization of interest rate, with the continuous improvement of the financial market market, non-bank social scale should get a relatively fixed value.

Continue to the model residual to carry out stability test,the test results are shown in Table 7 :

Table 7 Residual stability test results

\begin{tabular}{c|c|c}
\hline & coefficient & P \\
\hline LLC & -15.3563 & 0 \\
\hline ADF & 67.4520 & 0.0002 \\
\hline
\end{tabular}

From the test results, the LLC statistic and the ADF statistic is all less than 0.05 , so the sequence is a stationary sequence, indicating that there is a long-term stable equilibrium relationship among the five variables of ROA, NIS, UN, NPL and NSF.

\section{Conclusion}

Analyze conclusion. According to the results, we can clearly see that the effect of spread on the profitability of commercial banks is still greater than other factors. In the process of liberalization of interest rate, banks should firmly grasp the interest rate changes. After the central bank liberalizes the control of interest rates, interest rates entirely determined by the market.So grasp the market information and avoid information asymmetry are the focus of commercial banks in the next stage.

Commercial banks should establish a sound interest rate system, and vigorously cultivate risk management personnel. Only commercial banks can establish a sound interest rate system, and timely manage the interest rate risk can effectively improve the profits of commercial banks.In addition, commercial banks should raise their own pricing levels.

Commercial banks should increase the proportion of intermediary business and accelerate financial innovation. On the one hand, interest rate risk will bring fatal losses to commercial banks.At this stage, the ability of banks to prevent risks is low.So banks should reduce the proportion of interest income to total income and increase the profitability of intermediate business and other business. On the other hand, we find from the statistical description of the data that although the proportion of the middle business income has increased significantly, the highest is only about $30 \%$. And in developed countries, nearly $50 \%$ is the level.

Commercial banks should reduce the non-performing loan rate and do a good job for pre-loan 
review and post-loan management.

Suggest. For commercial bank, creat core competitiveness,improve the pricing capacity of financial products ,change the traditional business market positioning and vigorously develop the intermediary business is an effective way to get great profits.

Besides, improving interest rate risk management capabilities and promoting the management model reform can improve their own internal control mechanism step by step. At the same time ahead of monitoring and early warning force commercial banks to seek a more robust business through a sound regulatory system and stress testing system

\section{References}

[1] Nicholas Lardy. Interest Rate Liberalization and the International Role of the RMB[J]. pplied Economics, 2012, 20(6):29-54.

[2] Laeven L and Valencia F. Systemic banking crises database[J]. IMF Economic Review, 2013, 61(2): 225-270.

[3] Li Zhonglin. Interest Rate Marketization and Commercial Bank Risks [J]. Finance and Economics, 2015 (1): 36-46.

[4] Zhou Bing.Study on the Impact of Interest Rate Marketization on Commercial Banks[J] .Journal of Finance, 2013 (2);41-47.

[5] Tarhan Feyzioglu, Nathan Porter, and Elod Takats, Interest Rate Liberalization in China[J].IMF Working Paper, 2009, 58(9):1-28.

[6] Li Kechuan: interest rate marketization and China's small and medium-sized commercial banks: opportunities, challenges and enlightenment [J]. Finance and Economics, 2013 (1): 47-51.

[7] Zhang Hui.Study on the Strategy of Small and Medium-sized Banks to Deal with Interest Rate Marketization [J] .Journal of Finance, 2014 (1): 48-53.

[8] Peng Jiangang, Zou Ke, Zhang Yisheng.Study on the statistical relationship between the non performing loan rate on the banking industry [J].Journal of Hunan University (Social Science Edition), 2015,29 (05): 58-64.

[9] Liu Tian, Tan Jin, Shi Daimin.Selection of Sample Length in Unit Root Test [J] .Journal of Mathematical Statistics and Management, 2013,32 (04): 617-626.

[10]Chen Qingqing, Long Zhihe, Lin Guangping.Spatial Hausman Test of Panel Data [J]. Systems Engineering, 2012,30 (06): 95-99. 